\begin{tabular}{l} 
POLITEIA/ POLITEIA: Jurnal Ilmu Politik \\
Politeia, 12 (1) (2020): 28-40 \\
ISSN 0216-9290 (Print), ISSN 2549-175X (Online) \\
Available online https:/ / talenta.usu.ac.id/politeia \\
\hline
\end{tabular}

\title{
Analisis Konflik dan Resolusi (Studi Kasus : Rekrutmen Perangkat Desa di Kabupaten Demak Tahun 2017-2018)
}

\author{
Saipul Bahri* E Abdul Halim
}

\begin{abstract}
Magister Ilmu Politik, FISIP Universitas Diponegoro, Semarang, Indonesia
\end{abstract}
\begin{abstract}
Abstrak
Studi ini tentang resolusi konflik yang terjadi pada proses rekrutmen Perangkat Desa di Kabupaten Demak dengan rentang waktu Tahun 2017-2018. Fokusnya membahas tentang bagaimana politik hukum dan implementasi kebijakan rekrutmen perangkat desa di Kabupaten Demak, kemudian pada tataran konfliknya (sumber, manivestasi, dan durasi) Rekrutmen Perangkat Desa di Kabupaten Demak, serta Resolusi konflik yang sesuai terhadap persoalan yang dimunculkan dalam studi kasus ini . Kemudian pada tataran konflik pasca analisis muncul disebabnya karena penghilangan pasal dalam perda, dalam hal manivestasi muncul berbagai demonstrasi dan gugatan di PTUN terkait seleksi perangkat desa. Resolusi yang digunakan yang sesuai adalah 6 metode, seperti yang dikemukakan oleh Forsyth. Metode penelitian yang digunakan adalah mixed method dengan kualitatif lebih dominan. Hasil penelitian yaitu terdapat upaya penyalahgunaan wewenang pada saat perumusan dan implementasi kebijakan rekrutmen perangkat desa yang mengarah kepada konflik horizontal antar masyarakat di Kabupaten Demak dan juga konflik vertikal yakni antara masyarakat lokal dengan pemerintah daerah.
\end{abstract}

Kata Kunci: Politik Hukum, Implementasi Kebijakan, Resolusi Konflik.

\begin{abstract}
This study is a study of conflict resolution that occurred in the process of village apparatus recruitment in Demak Regency with a time span of 2017-2018. The focus discusses how the politics of law and the implementation of village apparatus recruitment policies in Demak Regency, then at the level of conflict (source, investment, and duration) Recruitment of Village Apparatuses in Demak District, as well as Conflict Resolution appropriate to the issues raised in this case study. Then in the conflict situation after the analysis arises because of the removal of the article in the local regulation, in the case of manifestation there were various demonstrations and lawsuits in the PTUN related to the selection of village officials. The appropriate resolution used is 6 methods, as stated by Forsyth. The research method used is mixed method with qualitative dominant. The findings of this study include an effort to abuse authority during the formulation and implementation of village apparatus recruitment policies that lead to horizontal conflicts between communities in Demak Regency and also vertical conflicts between local communities and local governments.
\end{abstract}

Keywords: Political Law, Policy Implementation, Conflict Resolution

How to Cite: Bahri, S \& Halim, A. (2019). Analisis Konflik dan Resolusi (Studi Kasus : Rekrutmen Perangkat Desa di Kabupaten Demak tahun 2017-2018). Politeia: Jurnal Ilmu Politik, 12 (1): 28-40

\footnotetext{
*Corresponding author:

E-mail: saipulbahrisipma@gmail.com
} 


\section{PENDAHULUAN}

Pada awal tahun 2017, Pemerintah Kabupaten Demak melalui Sekretaris Daerah

Pemerimtah Kabupaten Demak dr Singgih Setyono MMR menyampaikan hanya ada 463 jabatan yang tersebar di 201 desa, dalam perkembangannya kini tercatat ada 476 jabatan kosong yang tersebar di 199 desa. Jumlah tersebut diketahui setelah adanya data susulan dari beberapa desa yang melaporkan ke Pemerimtah Kabupaten Demak lewat kecamatan. Sebagaimana diberitakan di Radar Semarang, Lowongan Perangkat Desa Jadi 476 Jabatan. (Radar Semarang, 27 April 2018).

Demak sebagai daerah yang memiliki kewenangan atas desentralisasi kekuasaan yang mana dalam menjalankan pemerintahaan juga diberikan kewenangan kepada seorang Kepala Desa, kemudian Kepala Desa juga turut dibantu oleh Perangkat Desa. Proses pembuatan kebijakan merupakan proses yang kompleks (Nugroho, 2011)

Dalam rekrutmen dan seleksi perangkat desa, Pemerintah Kabupaten Demak dalam hal ini Bupati melakukan inisiatif agar proses berjalan lancer dan memiliki payung hukum melalui perumusan Rancangan Peraturan Daerah (Ranperda) tentang Pengangkatan dan Pemberhentian Perangkat Desa, harapannya dengan adanya Ranperda ini meminimalkan potensi konflik dalam rekrutmen/seleksi perangkat desa di Kabupaten Demak. Penolakan dan
Evaluasi Raperda agar banyak hal yang perlu dikaji datang dari DPRD Kabupaten Demak selaku mitra Pemerimtah Kabupaten Demak, selanjutnya juga ada dari Paguyuban Kepala Desa se-Kabupaten Demak, kemudian Lembaa Swadaya Masyarakat ataupun Lembaga Bantuan Hukum yang menyoroti ada pasal atau ayat dalam rancangan peraturan daerah yang cenderung menguntungkan salah satu pihak. Proses Rancangan Peraturan Daerah diawali tahun 2017 akhirnya berlarutlarut hingga tahun 2018.

Ada beberapa fenomena yang terjadi dan berkembang, antara lain munculnya kepentingan beberapa anggota Dewan Perwakilan Rakyat Daerah (DPRD) yang merepresentasikan atau mengutamakan kepentingan Pihak Legislatif untuk menyusun sebuah regulasi yang bisa mengamankan atau meloloskan calonnya yang menyebabkan terjadinya perbedaan pendapat antara Bupati selaku Kepala Daerah atau pihak eksekutif dengan DPRD secara kelembagaan selaku pihak legislatif, sehingga dalam proses penyusunan regulasi terkait seleksi Perangkat Desa sarat dengan kepentingan politik, padahal hakikat yang ingin dicapai adalah terisinya jabatan perangkat desa yang professional di Kabupaten Demak yang selama ini sudah lama terjadi kekosongan, sehingga pembangunan di Desa tidak bisa berjalan secara maksimal. 
Konflik yang terjadi dalam sebuah perumusan kebijakan publik merupakan hal yang wajar terjadi. Hal ini sebagaimana dikemukakan oleh Nugroho bahwa "Kebijakan publik muncul di tengah konflik dan sebagian besar untuk mengatasi konflik yang telah, sedang dan yang akan terjadi". (Nugroho, 2009: 305)

Peneliti dalam konsepsi rumusan masalah ingin fokus bagaimana konflik terjadi dan resolusi yang paling efektif untuk meminimalisir terjadinya konflik yang berkepanjangan sehingga didapatkan jalan keluar dari permasalahan rekruitmen perangkat desa di Kabupaten Demak.

\section{METODE PENELITIAN}

Penelitian ini menggunakan pendekatan kualitatif yang didukung pendekatan kuantitatif dengan metode survei. Penggunaan metode penelitian campuran atau mix method. Pendekatan kualitatif yaitu pendekatan penelitian yang berlandaskan pada filsafat postpositivisme yang digunakan untuk meneliti kondisi objek yang alamiah, dimana peneliti adalah sebagai instrument kunci, analisis data bersifat induktif/kualitatif lebih menekankan makna daripada generalisasi. Sedangkan pendekatan kuantitatif dengan menggunakan metode survei, merupakan penelitian yang mengambil sampel dari populasi dengan menggunakan kuesioner sebagai alat pengumpul data dan individu sebagai unit analisa. penelitian ini dilakukan di Kecamatan Sayung, Keacamatan Karangawen dan Kecamatan Dempet, yang dibagi lagi atas sejumlah 51 desa dan kelurahan terdiri dari 47 desa dan 4 kelurahan.

Sampel kualitatif dipilih dengan menggunakan teknik Purposive sampling dengan kriteria yang sudah ditentukan. Subjek utama untuk dilakukan wawancara ialah Bupati dan Ketua Komisi A DPRD Kabupaten Demak dan beberapa narasumber yang terkait control group yakni LSM Demak Raya, LKSP dan Ketua Assosiasi Perangkat Desa. Sedangkan subjeksubjek lainnya ialah tokoh masyarakat desa yang terlibat aktif dalam proses rekruitmen dan juga beberapa pihak yang dianggap dapat mendukung isi dan hasil penelitian ini.

\section{Pengolahan data kuantitatif} yang diperoleh melalui metode survey, dengan menggunakan angket dan diolah menggunakan statistik deskriptif (Sugiyono, 2009). Populasi yang digunakan pada penelitian ini adalah sampel dari populasi masyarakat yang terlibat dan mengetahui tentang kondisi di desa. Penentuan sampel dapat dilakukan dengan mengunakan rumus Slovin (Ridwan, 2005). Dengan populasi besaran di wilayah Demak yang melaksanakan seleksi perangkat desa yang berjumlah 47 desa berdampak dengan nilai kritis 10\% dengan jumlah sampel yang dibutuhkan yakni: 


$$
\mathrm{n}=\frac{\mathbf{N}}{\mathbf{N}[\mathbf{d}]^{2}+\mathbf{1}}
$$

Keterangan :

$\mathrm{n}$ : Jumlah sampel yang dicari

$\mathrm{N}$ : Jumlah populasi (di setiap kecamatan)

d : Tingkat presisi yang ditetapkan

$$
n=\frac{47}{1[47]^{2}+1}=6,22=6 \text { sampel }
$$

Sejumlah 47 Desa yang selenggarakan Pemilihan Kepala Desa yang akan menjadi sampel dalam penelitian ini tersebar ke dalam tiga Kecamatan, sampel akan diambil secara acak tanpa memperhatikan strata yang ada dalam populasi (Simple Random Sampling) berdasarkan Desa berdampak atas Konflik, karena peneliti menganggap anggota populasi bersifat homogen. Besaran sampel yang akan di ambil per kecamatan menggunakan rumus berikut:

Desa $=\underline{\text { Populasi Kecamatan }} \times$ T. Sampel Total Populasi

Tabel 1 Distribusi Sampel Per Kecamatan

\begin{tabular}{ccc}
\hline Kecamatan & Rumus & Sampel \\
\hline Sayung & $\frac{17}{47} \times 6=2,1$ & 2 \\
Karangawen & $\frac{19}{47} \times 6=2,4$ & 2 \\
Dempet & $\frac{11}{47} \times 6=1,4$ & 1 \\
& \\
\hline \multicolumn{2}{c}{ Total Sampel } & 5 Orang
\end{tabular}

Sumber : Hasil Olahan Data Peneliti, 2019.

\section{HASIL DAN PEMBAHASAN}

\section{Politik Hukum}

Penataan regulasi dan pengelolaan relasi kekuasaan merupakan persoalan yang sangat urgent dalam pembangunan demokrasi di daerah apalagi jika berkaitan anatara kepala daerah dan masyarakat. Berbagai polemik terkait kebijakan Bupati sering berujung pada perang opini di dalam sosial masyarakat. Salah satunya adalah dikeluarkannya Peraturan Daerah (perda) tentang Pengangkatan dan Pemberhentian Perangkat Desa Kabupaten Demak. Perda ini secara resmi disahkan oleh Bupati Demak pada rapat paripurna Dewan Perwakilan Rakyat Daerah (DPRD) Kabupaten Demak tahun 2018. Hal ini memberikan dampak munculnya eskalasi konflik yang cukup kompleks dan tidak dapat diprediksi. Seperti yang dijelaskan pada model teori Johan Galtung bahwa eskalasi politik merupakan puncak terjadinya suatu konflik, sehingga tidak bisa dipungkiri bahwa konflik di Kabupaten Demak bisa mengarah kepada kekerasan yang masyarakat meskipun pada dasarnya sudah mempunyai ketetapan hukum sebagai landasannya. Kepastian hukum dalam penyelenggaraan pemerintahan daerah semakin penting manakala dalam pembangunan di pemerintahan sangat mempengaruhi iklim investasi sosial yang diharapkan menjadi modal pembangunan daerah. 
Ketidaksinkronan kebijakan rel yang seharusnya dilalui (Mahfud Daerah dengan kebijakan bupati dinilai MD, 1998: 13). sebagai hambatan dalam optimalisasi kinerja investasi jalannya kondusifitas antar penyelenggara di Daerah. Hal itu tercermin dari terjadinya over regulasi di Daerah melalui banyaknya peraturan hukum di Daerah yang tumpang tindih dan bertentangan adalah kezaliman".

karena belum adanya tertib peraturan perundang-undangan.

Secara etimologis politik dan hukum adalah dua kata yang memiliki pengertian atau makna yang berbeda Politik berasal dari kata "polis" yang berarti negara kota, dengan politik berarti ada hubungan khusus antara manusia yang hidup bersama, dan dalam hubungan tersebut timbul aturan, kewenangan, kelakuan pejabat, legalitas keabsahan dan akhirnya kekuasaan (Inu Kencana Syafie \& Azhari, 2006: 6).

Bertolak dari pengertian politik dan hukum di atas maka dapat di maknai bahwa antara hukum dan politik memiliki keterkaitan yang erat, sebab bila politik dimaknai sebagai kekuasaan, maka untuk menjalankannya membutuhkan hukum sebagai alat untuk mewujudkannya Sri Soemantri mengkonstruksikan hubungan antara hukum dan politik di Indonesia ibarat perjalanan lokomotif kereta api yang keluar dari relnya Jika hukum diibaratkan sebagai rel dan politik diibaratkan sebagai lokomotif, maka sering terlihat lokomotif itu keluar dari
Sehingga semboyan yang mengatakan bahwa hukum dan politik harus bekerjasama dan saling menguatkan melalui ungkapan "hukum tanpa kekuasaan adalah angan-angan, kekuasaan tanpa hukum

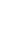

Gambar 1. Kerangka Teori Pembahasan

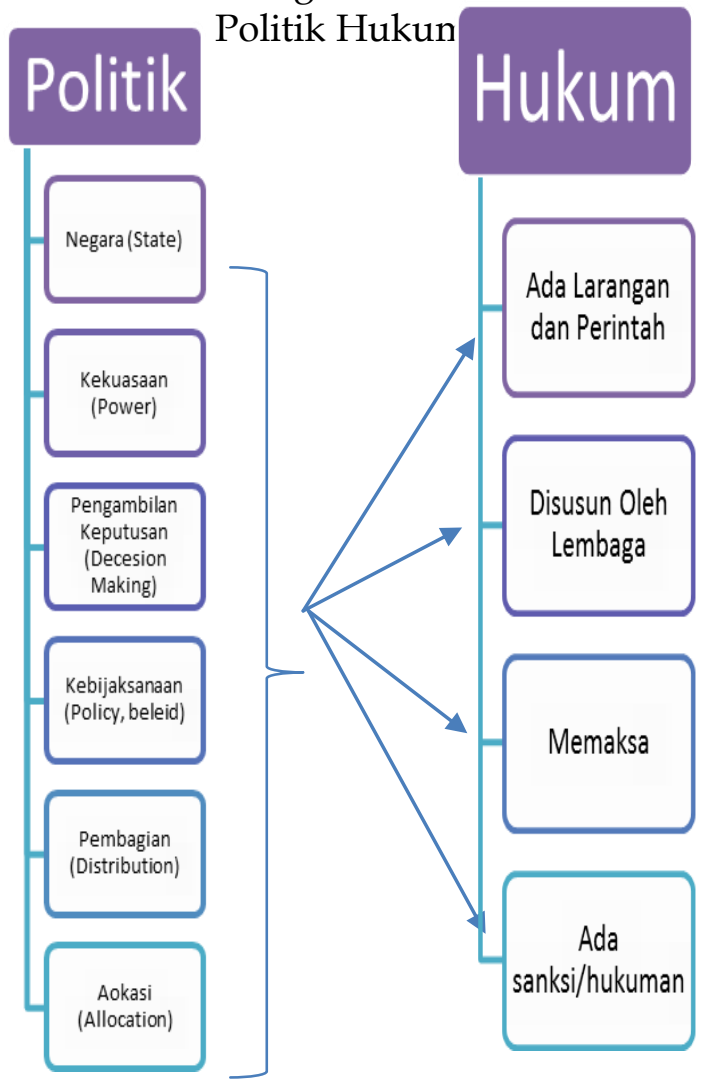

Sumber: Berbagai sumber yang diolah oleh Peneliti, 2018.

Penulis menentukan indikator dalam pembahasan bagian pertama ini, dalam konteks politik hukum, penulis akan menanyakan kepada responden maupun informan, utamanya terkait: 
a. Kesesuaian Perda dengan kenyataan social dan populistik.

b. Kecenderungan Perda atas visi yang diusung.

c. Keterbukaan Perda untuk dikritik (Pers, Masyarakat, dll).

d. Perda tidak bertentangan dengan aturan diatas.

e. Perda Perlu dipertahankan.

Dilihat dari proses perencanaan Peraturan Daerah Kabupaten Demak No 01 tahun 2018 berdasarkan fakta yang didapatkan maka dapat dianalisa bahwa perencanaan pembuatan Perda Kabupaten Demak No 01 tahun 2018 dikaitkan dengan teori politik hukum yang disajikan oleh para ahli menyimpang dari tujuan yang dicitacitakan yang mana dapat dikatakan pembuatan keluar dari rel aturan yang ada. Seperti yang di katakan Rifa'i bahwa pembuatan Perda Kabupaten Demak No 01 tahun 2018 oleh Pemda Kab Demak sangat dipengaruhi oleh kepentingan para penguasa politik dalam hal ini Bupati Demak dan Ketua Dewan Perwakilan Rakyat Daerah (DPRD) Kabupaten Demak tahun 2018.

Hal ini terlihat dari peran dan keikutsertaan dari penyampaian draf Raperda yang disempurnakan oleh Kepala Bagian Hukum Pemerintah Daerah Kabupaten Demak yang di dalamnya terdapat kepentingan investasi politik/kekuasaan dalam hal ini rekrutmen perangkat desa yang menjanjikan keuntungan bagi semua pihak yang berperan dalam menetapkan suatu payung hukum.

\section{Tabel 2 Jawaban Responden Atas Indikator Politik Hukum Perda}

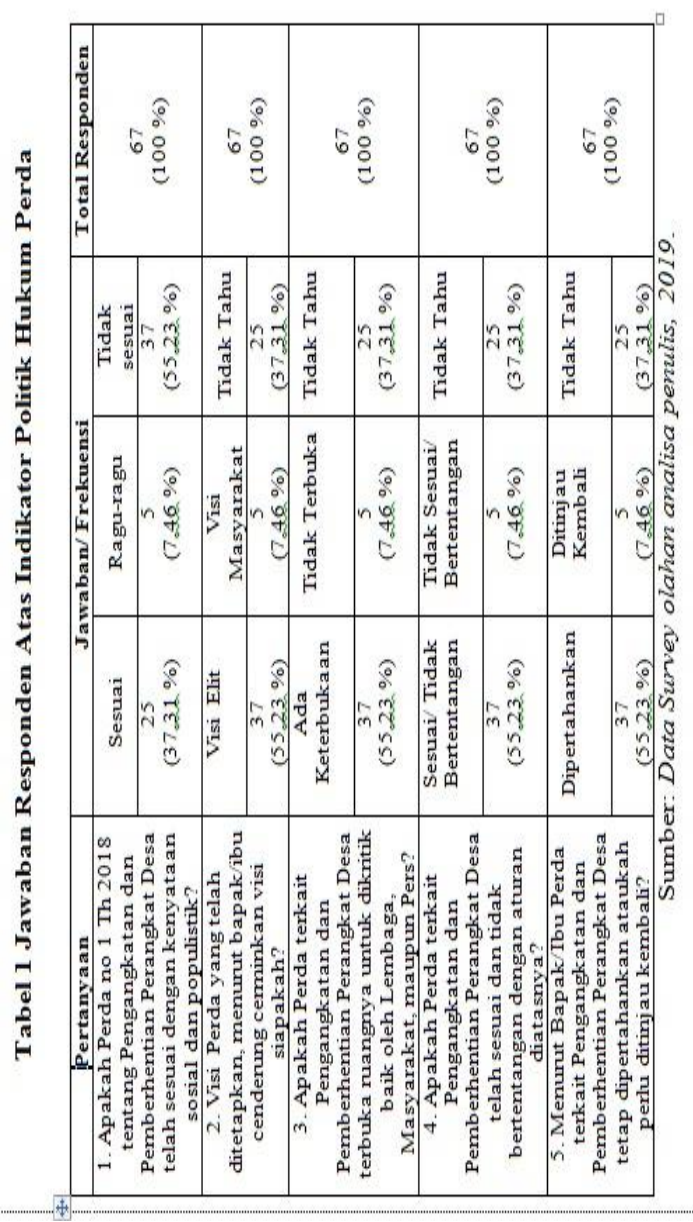

Sumber: Hasil Olah data peneliti, 2018

\section{Implementasi Kebijakan}

Implementasi merupakan aspek yang penting dari proses kebijakan, dimana menurut Nugroho (2009, h.494) implementasi pada prinsipnya adalah cara agar sebuah kebijakan dapat mencapai tujuannya. Terdapat dua pilihan dalam mengimplementasikannya, yakni langsung mengimplementasikannya dalam bentuk program, sedangkan yang kedua adalah melalui formulasi 
kebijakan derifat atau turunan dari kebijakan publik tersebut.

Pendapat Van Meter dan Van Horn, serta Mazmanian dan Sebatier, oleh Wahab (2012: 136), dijelaskan sebagai sebuah proses implementasi yang sesungguhnya tidak hanya menyangkut perilaku badan-badan per administratif, serta bertanggung jawab untuk melaksanakan program dan menimbulkan ketaatan pada diri kelompok sasaran, melainkan pula menyangkut jaringan-jaringan politik, ekonomi, dan sosial yang langsung atau tidak langsung dapat memengaruhi perilaku dari semua pihak yang terlibat. Sehingga akhirnya berpengaruh terhadap dampak yang dihasilkan, baik yang diharapkan maupun yang tidak diharapakan.

Otonomi daerah yang

dilaksanakan berdasarkan Undangundang Nomor 34 Tahun 2004 atau sekarang Undang - Undang Nomor 23 Tahun 2014 dan Undang-Undang Nomor 9 Tahun 2015 filosofinya adalah penguatan hak-hak politik dan pemberdayaan masyarakat, berbangsa dan bernegara yang demokratis, sehingga perlu menempatkan masyarakat desa sebagai bagian yang amat penting. Berbagai kebijakan negara yang terkait dengan hak-hak politik masyarakat desa telah lama ada, baik di jaman feodal, orde lama, orde baru sampai orde reformasi yang sedang berjalan saat ini.

Proses Implementasi Peraturan Daerah Kabupaten Demak Nomor 1 Tahun 2018 Tentang Pengangkatan
Dan Pemberhentian Perangkat Desa meliputi melakukan penjaringan dan penyaringan bakal calon perangkat desa sesuai persyaratan yang telah ditentukan, menerima pendaftaran dan kelengkapan persyaratan administrasi bakal calon perangkat desa, melakukan penelitian dan pemeriksaan identitas bakal calon perangkat desa berdasarkan ketentuan yang berlaku, menetapkan jadwal pelaksanaan pemilihan dan seleksi setelah mendapat persetujuan Badan Permusywaratan Desa (BPD), mengajukan rencana biaya seleksi perangkat desa kepada kepala desa, menjalin Memorandum Of Understanding (MoU) dengan pihak ketiga untuk membantu dalam tahapan seleksi perangkat desa.

Setelah mendapat persetujuan Badan Permusyawaratan Desa (BPD), menetapkan tempat, jadwal, tata tertib dan mekanisme seleksi bagi calon perangkat desa, mengumumkan calon perangkat desa yang berhak ikuti proses seleksi, mengadakan Fasilitasi panitia seleksi perangkat Desa oleh Bupati dan Camat, melaporkan dan menyampaikan hasil pelaksanaan Pemilihan Kepala Desa (Pilkades) kepada Badan Permusyawaran Desa

(BPD). 
Tabel 3 Jawaban Responden Atas Indikator Implementasi Kebijakan

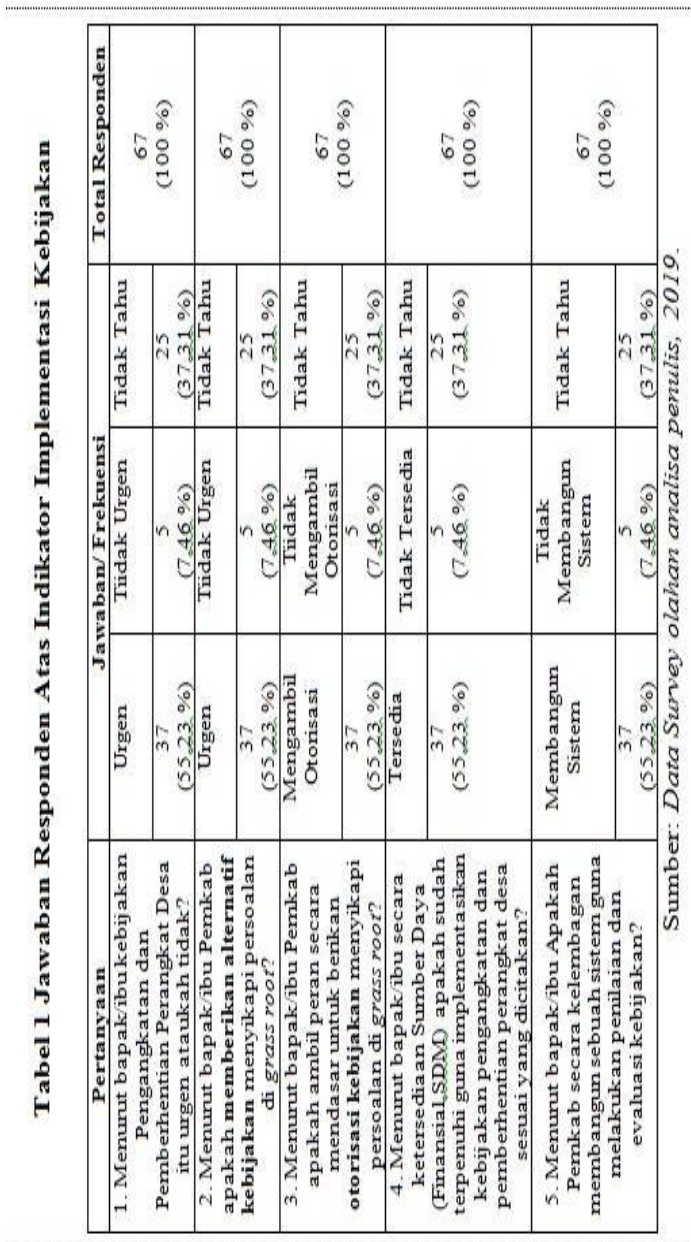

Sumber: Hasil Olah Data Peneliti, 2018

\section{Konflik Pengangkatan Pemberhentian Perangkat Desa}

Dimulainya konflik hingga bermuara pada resolusi tentu melewati tahapan-tahapan yaitu awal mula konflik dari sebuah perbedaan komunikasi yang terjadi. Konflik dalam komunikasi sering terjadi baik dalam hubungan interpersonal maupun kelompok atau organisasi. Adanya komunikasi dapat menyebabkan terjadinya konflik, tetapi di sisi lain, komunikasi yang terjadi itu sendiri dapat menjadi potensi terjadinya konflik. Timbulnya konflik atau pertentangan, merupakan suatu kelanjutan dari adanya komunikasi

dan informasi yang tidak menemui sasarannya. Terjadinya konflik dalam setiap organisasi merupakan sesuatu hal yang tidak dapat dihindarkan. Hal ini terjadi karena di satu sisi orangorang yang terlibat dalam organisasi mempunyai karakter, tujuan, visi, maupun gaya yang berbeda-beda. Di sisi lain adanya saling ketergantungan antara satu dengan yang lain yang menjadi karakter setiap organisasi.

Kebijakan dalam kegiatan penyelenggaraan sistem di suatu daerah sangatlah diperlukan guna menunjang pembangunan daerah tersebut. Hal ini diperlukan karena pada dasarnya dinamika demokrasi yang terjadi mempunyai satu kesatuan dari terjadinya kualitas perangkat penyelenggara pemerintahan daeerah. Terdapat beberapa hal terkait yang dapat menjadi rujukan dalam setiap kebijakan dalam memandang persoalan di seputar pemberhentian dan pengangkatan perangkat desa di Kecamatan Sayung Kabupaten Demak.

Peraturan daerah No 1 Tahun 2018 Tentang Perangkat Desa di Kabupaten Demak yang dimaksudkan menjadi instrumen hukum penyelenggaraan desentralisasi pemerintahan untuk menggerakkan sistem pemerintahan sekaligus kontrol terhadap pelanggaran pembangunan Daerah, justru menjadi faktor pengahambat pembangunan daerah. Karena hakekat kebijakan tersebut menimbulkan penolakan dari masyarakat yang merasa kepentingannya terganggu. Intervensi Bupati Demak yang begitu mendominasi memunculkan reaksi penolakan ini berjujung kepada terjadinya konflik sosial di Kecamatan Sayung. 
Tabel 4 Persepsi Responden Terhadap Sumber Konflik

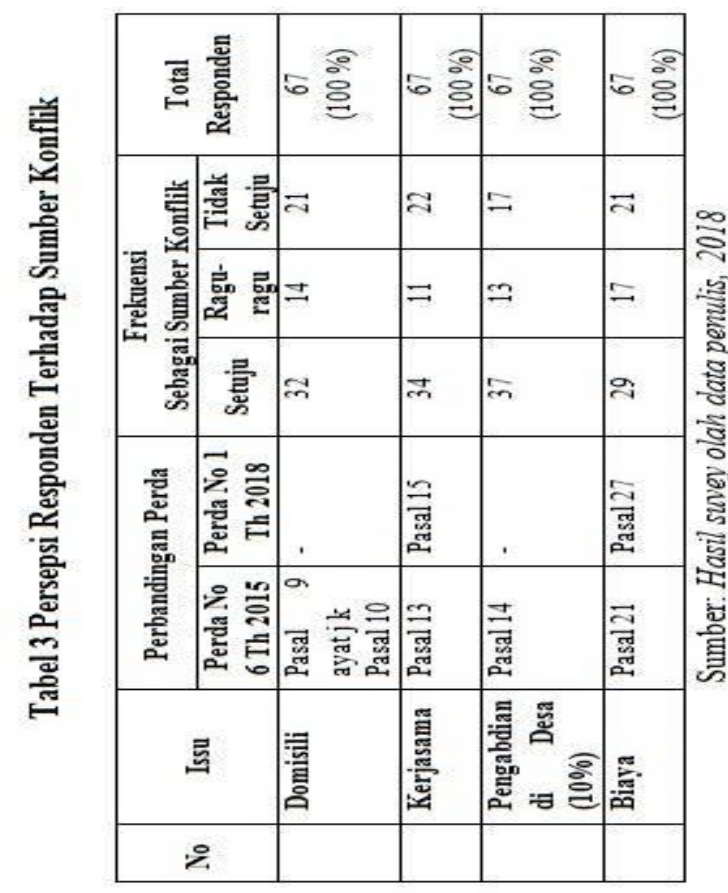

Sumber: Hasil Olah Data Peneliti, 2018

Dialektika dari kebijakan Peraturan Daerah di daerah Kabupaten Demak mengandung pengertian "benturan", seperti perbedaan pendapat, persaingan, dan pertentangan antara pihak-pihak tertentu. Dalam kasus ini konflik ditandai dengan adanya "benturan" kebijakan antara pemerintah dengan masyarakat mengenai penentuan kewenangan calon perangkat desa. Kebijakan institusi pemerintah sebagai lembaga merupakan keputusan politik yang merefleksikan juga kepentingan lembaga tersebut, sedangkan dalam proses pembuatan kebijakan sarat dengan muatan pengaruh. Untuk mengetahui bagaimana institusi politik beroperasi, bagaimana keputusan penting dibuat maka informan yang paling relevan adalah para elite politik. Elite didefinisikan sebagai "mereka yang berhubungan dengan, atau memiliki posisi penting. Elite politik berkaitan dengan seberapa kekuasaan seseorang berpengaruh pada pembuatan kebijakan pemerintah.

\section{Gambar 2: Bagan Dimensi Konflik Di} Kabupaten. Demak

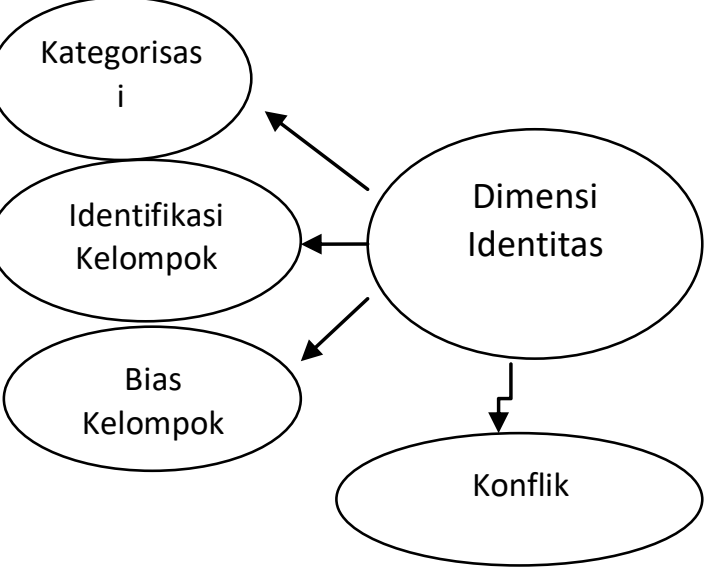

Sumber : Hasil olah data peneliti, 2018.

Sesuai dengan amanat UndangUndang Dasar Republik Indonesia Tahun 1945 dalam Pasal 18 ayat (6) disebutkan bahwa Pemerintah daerah berhak menetapkan peraturan daerah dan peraturan lain untuk melaksanakan otonomi dan tugas pembantuan, serta berdasarkan atas Pasal 25 huruf $b$ UndangUndang Nomor 32 Tahun 2004 tentang Pemerintahan Daerah disebutkan bahwa Kepala daerah mempunyai tugas dan wewenang dalam menetapkan Perda yang telah mendapat persetujuan bersama DPRD. Untuk itulah dalam menjalankan pemerintahan daerah salah satu kewenangan pemerintahan daerah adalah dalam hal pembuatan peraturan daerah. 
Pro kontra dan aksi protes yang dilakukan oleh masyarakat dan tokoh pemuda dan mereka kemudian melakukan memberikan somasi/peringatan kepada kepala daerah agar mencabut perda tersebut dan meminta ketegasan Bupati untuk memperhitungkan local wisdom yang ada di masyarakat Kabupaten Demak. Situasi konflik akan selalu berubah dari waktu ke waktu apabila konflik tersebut terus dibiarkan terjadi tanpa adanya upaya penanganan atau penyelesaian yang dilakukan oleh pihak-pihak yang berkonflik dalam hal ini di dominasi kebijakan dari Bupati Demak.

Masyarakat itu selalu dalam perubahan dan setiap elemen dalam masyarakat selalu memberikan sumbangan bagi terjadinya konflik. (Fisher (2001:75).

Salah satu penyebab terjadinya konflik adalah karena ketidak seimbangan antara hubunganhubungan manusia seperti aspek sosial, ekonomi dan kekuasaan.

\section{Resolusi Konflik}

Konflik pengangkatan dan pemberhentian perangkat desa berawal dikeluarkannya Perda No. 1 Tahun 2018 yang kemudian diturunkan melalui Peraturan Bupati Kabupaten Demak, yang melakukan intervensi terhadap pengangkatan dan pemberhentian perangkat desa di Kecamatan Sayung. Oleh karena itu, protes ini dipicu oleh adanya sebagian masyarakat yang mendaftarkan diri untuk menjadi perangkat desa yang mana ia bukan merupakan masyarakat asli yang menempati daerah tersebut untuk mengisi posisi perangkat desa dimana ia di perintahkan oleh kebijakan yang dikeluarkan.

\section{Gambar 3. Pohon Konflik \\ Rekrutmen Perangkat Desa di Kabupaten Demak}

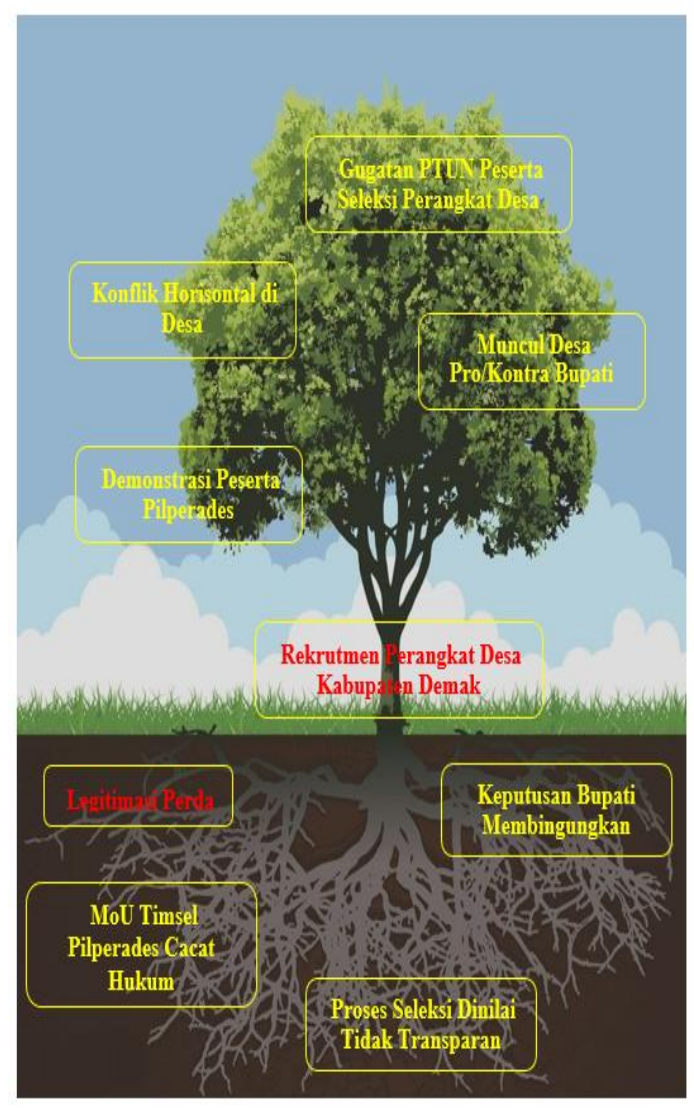

Sumber: Analisis peneliti, 2019.

Penyebab konflik yang terjadi, berdasarkan pohon konflik diatas adalah karena persoalan legitimasi Perda hal ini juga berimbas pada pasalpasal yang ada dalam Perda yang menurut beberapa pihak tidak sesuai kondisi sosial masyarakat.

Faktor penyebab konflik atau sumber konflik. Sumber konflik adalah adanya perbedaan dan perbedaan tersebut bersifat mutlak, yang artinya secara obyektif memang berbeda. Perbedaan tersebut dapat terjadi pada 
tataran antara lain: (1) perbedaan persepsi; (2) perbedaan pengetahuan; (3) perbedaan tata nilai; (4) perbedaan kepentingan; dan (5) perbedaan pengakuan hak kepemilikan (klaim). Tentu di dalam perspektif Perda yang dikeluarkan oleh Bupati Demak setidaknya mengacu kepada 2 faktor penting penyebab munculnya konflik tersebut, yakni perbedaan persepsi dan perbedaan kepentingan. (Yumi, 2012: 9),

Resolusi konflik adalah suatu tahapan yang diinginkan bagi orang atau kelompok yang terlibat di dalam keadaan konflik. Penyelesaian suatu konflik diharapkan dapat memberikan kedamaian, sehingga nantinya tidak menimbulkan suatu permasalahan baru yanng mengakibatkan konflik kembali terjadi. Resolusi konflik terhadap kebijakan yang dikeluarkan melalui Peraturan Daerah No 1 Tahun 2018 di Kabupaten Demak pada akhirnya harus menemui untuk bersinergi para pihak untuk membentuk forum perdamaian yang nantinya tidak menyakiti pihak lain, sehingga kondusifitas perangkat desa bisa berfungsi sebagaimana mestinya.

\section{Bagan 3 Gambaran Umum Konflik di Kabupaten Demak}

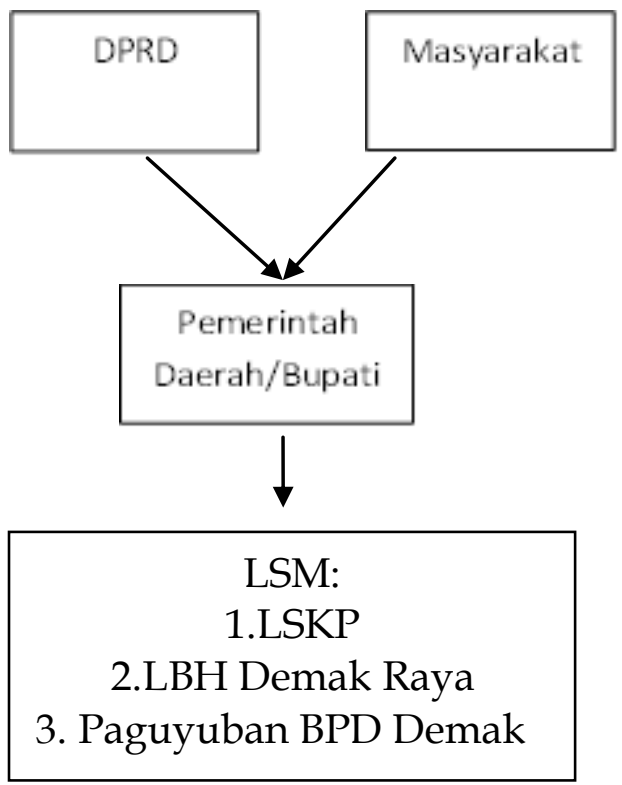

Data Diolah Peneliti, 2018

Robbins mengatakan bahwa konflik muncul karena ada kondisi yang melatarbelakanginya (antecedent conditions). Kondisi tersebut, yang disebut juga sebagai sumber terjadinya konflik, terdiri dari tiga ketegori, yaitu: komunikasi, struktur, dan variabel pribadi. Sehingga konflik yang tercermin yang terjadi di Kabupaten Demak melibatkan objek yang secara langsung bersentuhan langsung dengan kondisi dilapangan. Sebelumnya, konflik terjadi disebabkan karena adanya kebijakann yang dikeluarkan oleh Bupati terkait dengan Perangkat Desa, sehingga bagi peneliti pelaksanaan resolusi konflik yang ada di Kabupaten Demak tidak bisa kemudian dilepaskan dari 6 metode, seperti yang dikemukakan oleh Forsyth, ada beberapa metode untuk melakukan pelaksanaan resolusi 
konflik, sehingga dapat mengubah Konflik ini juga menunjukkan karena anggota kelompok yang berselisih lemahnya sosialisasi yang dilakukan menjadi sebuah perdamaian dan sebelum dikeluarkannya kebijakan. penyelesaian yang akur, di antaranya Lemahnya sosialisasi mendorong sikap adalah sebagai berikut:

1. Commitment $=>$ Negotiation

2. Misperception $=>$ Understanding apatis sehingga kebijakan tidak diiringi oleh partisipasi yang tinggi dari

3. Strong Tactics $=>$ Cooperative masyarakat, dan ketika masalah Tactics : a. Avoiding, b. Yielding, $c$. Fighting, $d$. Cooperating.

4. Upward $=>$ Downward Conflict Spirals

5. Many $=>$ One

6. Anger $=>$ Composure

\section{Bagan Alternatif Resolusi Konflik di Kabupaten Demak}

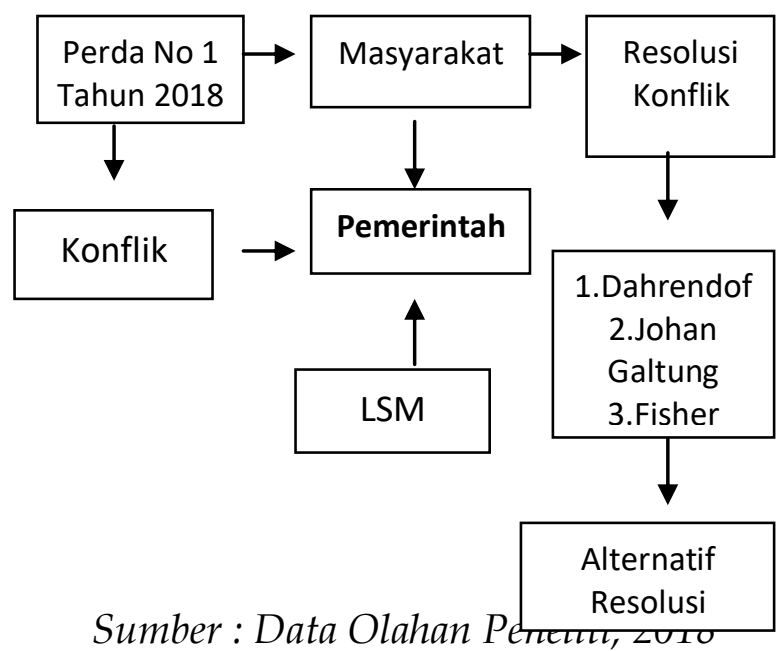

\section{SIMPULAN}

Terjadinya konflik pada rekruitmen perangkat desa di Kabupaten Demak tidak bisa terlepas dari orientasi politik. Kasus pemberhentian dan pengangkatan perangkat desa di Kabupaten Demak menyita banyak perhatian diawal keluarnya perda. Hal ini disebabkan adanya masalah yang menyertai masuknya pasal-pasal yang bernuansa kepentingan sepihak oleh kepala daerah. merebak dan antara pihak saling memojokkan maka muncullah distrust. Penyelesaian konflik yang kemudian dilakukan juga tidak memungkinkan menyelesaikan masalah secara total, hasil penelitian ini menunjukkan bahwa terdapat beberapa potensi konflik yang bisa berkembang.

\section{DAFTAR PUSTAKA}

Creswell, J.W. (2010) "Research Desain: Pendekatan Kuantitaf, Kualitatif dan Mixed., Yogyakarta, PT.Pustaka Indonesia.

Dwijowijoto, Riant Nugroho. 2003. Kebijakan Publik: Formulasi, Implementasi, dan Evaluasi. Jakarta: PT Elek Media Kompetindo.

Fisher, Simon, dkk. (2001) Mengelola Konflik: Keterampilan dan Strategi Untuk Bertindak. The British Council. Jakarta.Hardiansyah.

Hardiansyah. (2011). Kualitas Pelayanan Publik: Konsep, Dimensi, Indikator dan Implementasinya. Yogyakarta: Gava Media.

Muluk, M. R K. (2008). Knowledge Management: Kunci Sukses Inovasi Pemerintahan Daerah. Malang: Bayumedia.

Mahfud, MD. (2007). Politik Hukum di Indonesia. Bandung: PT. Citra Aditya Bhakti. 
Sugiyono. (2016). Metode Penelitian

Kombinasi (Mixed Method). Bandung:

Alfabeta.

Tjoroamidjojo, B. (2001). Reformasi Administrasi Publik. Jakarta: PPs Ilmu Administrasi Universitas Krisnadwipayana.

Yumi, Endang Dewi, dkk. (2012). Pengelolan Konflik Sumber Daya Hutan. Jakarta: Kementerian Kehutanan, Badan Pengembangan dan Penyuluhan SDM Kehutanan.

PERATURAN

Keputusan Menteri Pendayagunaan Aparatur Negara Nomor 63 Tahun 2003 Tentang Pedoman Umum Penyelenggaraan Pelayanan Publik. 2003. Jakarta.

Undang-Undang Nomor 25 Tahun 2009 Tentang Pelayanan Publik. 2009. Jakarta.

MEDIA ONLINE

Radar Semarang, Lowongan Perangkat Desa Jadi 476 Jabatan, http://radarsemarang.com/2017/01/ 20/lowongan-perangkat-desa-jadi476-jabatan/ diupload 20 Januari 2017, didownload 27 April 2018.

rival al-manaf, Rapat Revisi Perda Perangkat Desa di Kabupaten Demak Diwarnai Keributan Artikel ini telah tayang di Tribunjateng.com 25 Januari 2017, http://jateng.tribunnews.com/2017/ 01/25/rapat-revisi-perdaperangkat-desa-di-kabupatendemak-diwarnai-keributan. Didownload 27 April 2018 